\title{
Penerapan Model Problem Based Learning untuk Meningkatkan Hasil Belajar IPA Materi Kelainan Otot Manusia pada Peserta didik Kelas V Sekolah Dasar
}

\author{
Yanti Purwanti \\ SD N Laren 04 \\ yantipretty840@gmail.com
}

\section{Article History \\ received 3/12/2020}

revised $17 / 12 / 2020$

\begin{abstract}
The application of innovative learning models can affect student learning outcomes. Based on observations at SD N Laren 04, the conditions include: students tend to be passive in learning, the learning method used is still monotonous, only lectures, question and answer and have not involved students to make discoveries independently or in groups. This study aims to improve science learning outcomes for muscle disorders in humans with the research subjects being all students of class V SD N Laren 04, totaling 12 students. This research is a classroom action research conducted in two cycles. Each cycle in this study went through the stages of planning, implementation, observation, and reflection. Data collection techniques used are observation and field notes. The results showed that the results of observations in the first cycle of $64 \%$ and in the second cycle increased to $88 \%$. Based on the results of the study, it can be concluded that the application of the Problem Based Learning model can improve science learning outcomes for human muscle disorders in class V SD N Laren 04.
\end{abstract}

Keywords: problem based learning, science, human muscle disorders

\begin{abstract}
Abstrak
Penerapan model pembelajaran yang inovatif dapat mempengaruhi hasil belajar peserta didik. Berdasarkan observasi di SD N Laren 04 menunjukkan kondisi antara lain : peserta didik cenderung pasif dalam pembelajaran, metode pembelajaran yang digunakan masih monoton hanya ceramah, Tanya jawab dan belum melibatkan peserta didik untuk melakukan penemuan secara mandiri ataupun kelompok. Penelitian ini bertujuan untuk meningkatkan hasil belajar IPA materi kelainan otot pada manusia dengan subjek penelitiannya adalah semua peserta didik kelas V SD N Laren 04 yang berjumlah 12 peserta didik. Penelitian ini merupakan penelitian tindakan kelas yang dilaksanakan sebanyak dua siklus. Setiap siklus dalam penelitian ini melalui tahapan perencanaan, pelaksanaan, observasi, dan refleksi. Teknik pengumpulan data yang digunakan adalah observasi dan catatan lapangan. Hasil penelitian menunjukkan bahwa hasil observasi pada siklus 1 sebesar $64 \%$ dan pada siklus II mengalami kenaikan menjadi sebesar $88 \%$. Berdasarkan hasil penelitian dapat disimpulkan bahwa penerapan model Problem Based Learning dapat meningkatkan hasil belajar IPA materi kelainan otot manusia pada kelas V SD N Laren 04.
\end{abstract}

Kata kunci: problem based learning, IPA, kelainan otot manusia

Social, Humanities, and Education Studies (SHEs): Conference Series https://jurnal.uns.ac.id/shes

p-ISSN 2620-9284

e-ISSN 2620-9292 


\section{PENDAHULUAN}

IPA adalah mata pelajaran yang mengkaji fenomena-fenomena alam. IPA merupakan salah satu mata pelajaran yang dianggap paling tepat untuk menanamkan pengetahuan, sikap, dan keterampilan pada peserta didik melalui proses pembelajaran. Ilmu Pengetahuan Alam (IPA) atau sains merupakan ilmu pengetahuan yang mempelajari tentang seluruh alam semesta beserta isinya dan termasuk semua peristiwa-peristiwa yang terjadi di dalamnya, baik itu berupa fakta-fakta, konsepkonsep maupun prinsip-prinsip yang semuanya terorganisir dan sistematis sehingga menjadi suatu proses untuk memproduksi pengetahuan. Pada proses belajar IPA, peserta didik dituntut untuk dapat menemukan dan membangun pengetahuan secara mandiri sehingga pengetahuan yang peserta didik miliki lebih bermakna.

Namun pada kenyataannya peserta didik belum mampu membangun pengetahuannya secara mandiri yang mengakibatkan kurang maksimalnya hasil belajar IPA. Menurut Purwanto (2011:46) Hasil belajar adalah perubahan perilaku yang terjadi setelah mengikuti pembelajaran sesuai dengan tujuan pendidikan dalam domain kognitif, afektif dan psikomotorik. Dalam domain kognitif diklasifikasikan menjadi kemampuan hapalan, pemahaman, penerapan, analisis, sintesis, dan evaluasi. Dalam domain afektif hasil belajar meliputi level penerimaan, partisipasi, penilaian, organisasi, dan karakterisasi. Sedang domain psikomotorik terdiri dari level persepsi, kesiapan, gerakan terbimbing, gerakan terbiasa, gerakan kompleks dan kreativititas.

Menurut pendapat Munandi (dalam Rusman, 2012: 124) faktor yang mempengaruhi hasil belajar meliputi faktor internal dan faktor eksternal, yaitu: 1) Faktor Internal, yaitu a) Faktor fisiologis, kondisi kesehatan yang prima, tidak dalam keadaan lelah dan capek, tidak dalam keadaan cacat jasmani, dan sebagainya b) Faktor psikologis, meliputi intelegensi (IQ), perhatian, minat, bakat, motif, motivasi, kognitif, dan daya nalar siswa. 2) Faktor Eksternal yaitu: a) Faktor lingkungan, meliputi lingkungan fisik dan lingkungan sosial misalnya suhu, kelembaban, dan lainlain, b) Faktor instrumental, yaitu berupa kurikulum, sarana, dan guru.

Berdasarkan hasil observasi hasil belajar IPA materi kelainan otot manusia pada peserta didik kelas V SD N Laren 04 masih rendah. Hal ini disebabkan karena peserta didik cenderung pasif dalam pembelajaran, metode pembelajaran yang digunakan masih monoton hanya ceramah, Tanya jawab dan belum melibatkan peserta didik untuk melakukan penemuan secara mandiri ataupun kelompok.

Melihat permasalahan di atas, maka dibutuhkan adanya perbaikan dalam pembelajaran IPA agar tujuan pembelajaran IPA di kelas dapat tercapai secara maksimal. Upaya perbaikan proses pembelajaran adalah dengan membangun suasana belajar yang bermakna, guru perlu menerapkan model pembelajaran yang inovatif dan menyenangkan yang dapat memfasilitasi peserta didik untuk membangun pengetahuannya secara mandiri, mampu membantu peserta didik untuk aktif sehingga hasil belajar dapat meningkat.

Hal tersebut diatas menandakan bahwa adanya permasalahan yang perlu dicari solusi untuk memecahkan permasalahan tersebut. Mengingat guru mempunyai peranan besar dalam proses pembelajaran, maka guru diharuskan untuk selalu proaktif dan responsif terhadap hal-hal yang terjadi di dalam kelas maupun di lingkungan peserta didik. Perlu adanya inovasi terhadap model yang digunakan saat pembelajaran untuk meningkatkan aktivitas peserta didik sehingga dapat meningkatkan hasil belajar peserta didik.

Salah satu model pembelajaran yang inovatif dan mengaktifkan peserta didik yaitu model Problem Based Learning (PBL). Menurut Sani (2015: 127) Problem Based Learning ( $P B L)$ merupakan pembelajaran yang penyampaiannya dilakukan dengan cara menyajikan suatu permasalahan, mengujikan pertanyaan-pertanyaan, memfasilitasi penyelidikan, dan membuka dialog. Pembelajaran berbasis masalah 
atau Problem Based Learning (PBL) adalah pendekatan pembelajaran menggunakan masalah autentik sebagai sumber belajar sehingga peserta didik dilatih berpikir tingkat tinggi dan mengembangkan kepribadian melalui masalah dalam kehidupan sehari-hari (Uno dan Mohammad, 2015: 112).

Tujuan model problem based learning adalah meningkatkan kemampuan intelektual peserta didik, keterampilan berpikir dan pemecahan masalah, sehingga peserta didik menjadi pelajar yang mandiri. Hal tersebut didukung oleh pendapat Sugiyono, (2012: 156) model problem based learning dirancang dengan tujuan untuk meningkatkan keterampilan intelektual, dan investigative, memahami peran orang dewasa dan membantu peserta didik untuk menjadi pelajar yang mandiri.

Penerapan model problem based learning pada penelitian ini berfokus pada hasil belajar IPA materi kelainan otot manusia pada kelas $\mathrm{V}$ yang diharapkan dapat meningkatkan hasil belajar peserta didik kelas V SD N Laren 04.

Berdasarkan uraian permasalahan di atas ,maka penulis mencoba melakukan penelitian tindakan kelas (PTK) yang berjudul : "Penerapan Model Problem Based Learning Untuk Meningkatkan Hasil Belajar IPA Materi Kelainan Otot Manusia Pada Peserta didik Kelas V SD N Laren 04 “.

\section{METODE}

Penelitian ini merupakan penetitian tindakan kelas (PTK). Menurut pendapat Suharsimi (2011:3) penelitian tindakan kelas merupakan suatu pencermatan terhadap kegiatan belajar berupa sebuah tindakan, yang sengaja diumculkan dan terjadi dalam sebuah kelas secara bersama. Penelitian tindakan kelas itu sendiri mengharuskan guru untuk selalu berusaha melakukan tindakan pembaharuan (inovasi) dalam proses belajar mengajar. Prosedur pelaksanaan penelitian tindakan kelas berdasarkan Kurt Lewin (Arikunto, 2013: 131) bahwa terdiri dari empat tahap, yakni perencanaan, tindakan, pengamatan, dan refleksi. Subjek dalam penelitian ini adalah peserta didik kelas V SD N Laren 04. Dengan jumlah peserta didik sebanyak 12 peserta didik yang terdiri dari 6 peserta didik laki-laki dan 6 peserta didik perempuan. Objek penelitian ini adalah materi IPA kelainan otot pada manusia. Data yang digunakan berupa data kualitatif dan kuantitatif. Data kualitatif berupa deskripsi hasil observasi terhadap aktivitas peserta didik pada saat melaksanakan pembelajaran, selain itu data kualitatif berupa lembar observasi mengenai penerapan model Problem Based Learning dalam meningkatkan hasil belajar IPA materi Kelainan otot manusia pada peserta didik kelas V SD N Laren 04. Data kuantatif berupa nilai hasil belajar peserta didik kelas V dengan rentang nilai 0 sampai 100 . Nilai tersebut diperoleh dari hasil tes formatif yang dikerjakan peserta didik pada setiap siklus. Nilai hasil belajar peserta didik selanjutnya dirata-rata untuk menemukan rata-rata keberhasilan peserta didik secara klasikal. Tehnik pengumpulan data dalam PTK ini dilaksanakan dengan observasi dan catatan lapangan. Observasi dilaksanakan dengan dua cara pretest dan post tes. Pretest dilaksanakan untuk mengukur tingkat kemampuan mengerjakan soal IPA materi kelainan otot manusia di awal. Post tes dilaksanakan dengan menggunakan lembar tes yang dilaksanakan dengan mengerjakan soal IPA materi kelainan otot manusia dengan menerapkan model Problem Based Learning.

\section{HASIL DAN PEMBAHASAN}

Penelitian ini merupakan penelitian tindakan kelas yang dilaksanakan sebanyak dua siklus untuk mengetahui bagaimana peningkatan hasil belajar IPA materi kelainan otot manusia pada peserta didik kelas V SD N Laren 04. Pada tiap siklusnya terdiri dari satu tindakan yang diwujudkan dalam satu kali pertemuan pembelajaran yang lamanya 2 x 35 menit. Setiap siklus dalam penelitian ini melalui tahapan perencanaan, pelaksanaan, observasi, dan refleksi. Pada tahap perencanaan yang meliputi menyusun rencana pelaksanaan pembelajaran (RPP), membuat lembar evaluasi tes 
tertulis, menyiapkan lembar pengamatan, guru mengadakan evaluasi, guru menganalisis hasil evaluasi, guru mengadakan perbaikan pada peserta didik yang mendapat nilai kurang dari KKM dengan kembali mengerjakan soal latihan. Setelah perencanaan, dilakukanlah pelaksanaan perbaikan pembelajaran yang meliputi kegiatan awal, kegiatan inti, dan kegiatan akhir pembelajaran, serta tindak lanjut. Selanjutnya, pengamatan yaitu analisis terhadap hasil belajar yang sudah didapatkan untuk kemudian dilakukan refleksi yang bertujuan untuk menilai dan mengamati apa yang telah terjadi selama pembelajaran berlangsung untuk kemudian dilakukan perbaikan terhadap kekurangan- kekurangan yang ditemukan dalam proses pembelajaran.

Pada siklus I pembelajaran dilaksanakan selama dua pertemuan, setiap pertemuan diadakan pre test dan post test. Untuk mengetahui perkembangan peserta didik selama pembelajaran. Siklus I melakukan pembelajaran IPA materi kelainan otot manusia dengan menggunakan metode pembelajaran yang masih monoton hanya ceramah, Tanya jawab dan belum melibatkan peserta didik untuk melakukan penemuan secara mandiri ataupun kelompok.

Tabel 1. Hasil Belajar IPA Peserta didik Kelas V SD N Laren 04 Siklus I

\begin{tabular}{|c|c|c|c|c|c|c|c|c|}
\hline \multirow[t]{3}{*}{ Siklus I } & \multicolumn{4}{|c|}{ Pretest } & \multicolumn{4}{|c|}{ Post Test } \\
\hline & \multicolumn{2}{|c|}{$\begin{array}{l}\text { PESERTA } \\
\text { DIDIK } \\
\text { TUNTAS }\end{array}$} & \multicolumn{2}{|c|}{$\begin{array}{c}\text { PESERTA } \\
\text { DIDIK } \\
\text { BELUM } \\
\text { TUNTAS } \\
\end{array}$} & \multicolumn{2}{|c|}{$\begin{array}{l}\text { PESERTA } \\
\text { DIDIK } \\
\text { TUNTAS }\end{array}$} & \multicolumn{2}{|c|}{$\begin{array}{l}\text { PESERTA } \\
\text { DIDIK } \\
\text { BELUM TUNTAS }\end{array}$} \\
\hline & JML & $\%$ & JML & $\%$ & JML & $\%$ & JML & $\%$ \\
\hline PERTEMUAN 1 & 4 & 33,3 & 8 & 66,6 & 5 & 41,6 & 7 & 58,3 \\
\hline PERTEMUAN 2 & 5 & 41,6 & 7 & 58,3 & 8 & 66,6 & 4 & 33,3 \\
\hline
\end{tabular}

Berdasarkan tabel di atas dapat dijelaskan bahwa dalam proses pembelajaran ada peningkatan antara pre test dan post test pada pertemuan 1. Hasil belajar peserta didik sudah mengalami peningkatan pada pertemuan 1. Ketuntasan klasikal juga mengalami peningkatan, pada pre test hanya terdapat 4 peserta didik yang sudah tuntas, tetapi pada post test bertambah menjadi 5 peserta didik yang sudah tuntas dengan Kriteria Ketuntasan Minimal (KKM) sebesar 70. Demikian juga pada pertemuan 2 jumlah peserta didik yang sudah tuntas KKM mengalami peningkatan. Pada pre test ada 5 peserta didik yang baru tuntas, sudah meningkat menjadi 8 peserta didik yang tuntas setelah melaksanakan post test. Perbandingan antara hasil post test pada pertemuan 1 dan pertemuan 2 juga terdapat perbedaan. Pada pertemuan 1 peserta didik yang sudah tuntas hanya ada 5 peserta didik, sedangkan pada pertemuan 2 sudah meningkat menjadi 8 peserta didik.

Berdasarkan refleksi pada siklus I, maka dilanjutkan ke siklus II dengan alasan belum mencapai ketuntasan yang diharapkan. Siklus II membahas materi IPA tentang kelainan otot manusia dengan menerapkan model pembelajaran Problem Based Learning. Berikut ini adalah hasil belajar IPA peserta didik kelas V SD N Laren 04 pada siklus II yang bisa dilihat pada tabel berikut.

Tabel 2. Hasil Belajar IPA Peserta didik kelas V SD N Laren 04 Siklus II

\begin{tabular}{|c|c|c|c|c|c|c|c|c|}
\hline \multirow[t]{3}{*}{ SIKLUS II } & \multicolumn{4}{|c|}{ PRETEST } & \multicolumn{4}{|c|}{ POST TEST } \\
\hline & \multicolumn{2}{|c|}{$\begin{array}{l}\text { PESERTA } \\
\text { DIDIK } \\
\text { TUNTAS }\end{array}$} & \multicolumn{2}{|c|}{$\begin{array}{c}\text { PESERTA DIDIK } \\
\text { BELUM } \\
\text { TUNTAS }\end{array}$} & \multicolumn{2}{|c|}{$\begin{array}{l}\text { PESERTA } \\
\text { DIDIK } \\
\text { TUNTAS }\end{array}$} & \multicolumn{2}{|c|}{$\begin{array}{c}\text { PESERTA } \\
\text { DIDIK } \\
\text { BELUM } \\
\text { TUNTAS }\end{array}$} \\
\hline & JML & $\%$ & JML & $\%$ & JML & $\%$ & JML & $\%$ \\
\hline PERTEMUAN 1 & 7 & 66,7 & 5 & 33,3 & 9 & 75 & 3 & 25 \\
\hline PERTEMUAN 2 & 9 & 75 & 3 & 25 & 10 & 83,3 & 2 & 16,7 \\
\hline
\end{tabular}


Berdasarkan tabel di atas maka terjadi peningkatan antara pre test dan post test pada pertemuan 1. Setiap peserta didik sudah mengalami peningkatan hasil belajarnya. Ketuntasan klasikal juga mengalami peningkatan, pada pre test hanya terdapat 7 peserta didik yang sudah tuntas, tetapi pada post test bertambah menjadi 9 peserta didik yang sudah tuntas dengan Kriteria Ketuntasan Minimal (KKM) sebesar 70. Demikian juga pada pertemuan 2 jumlah peserta didik yang sudah tuntas KKM mengalami peningkatan. Pada pre test ada 9 peserta didik yang baru tuntas, sudah meningkat menjadi 10 peserta didik yang tuntas setelah melaksanakan post test. Perbandingan antara hasil post test pada pertemuan 1 dan pertemuan 2 juga terdapat perbedaan. Pada pertemuan 1 peserta didik yang sudah tuntas hanya ada 9 peserta didik, sedangkan pada pertemuan 2 sudah meningkat menjadi 10 peserta didik. Persentase ketuntasan klasikalnya meningkat, jika pertemuan 1 hanya $75 \%$ maka pada pertemuan 2 menjadi 83,3\%.

Berdasarkan hasil dari penelitian dan observasi dari setiap siklus menunjukkan bahwa hasil belajar peserta didik terus meningkat mulai dari pre test dan post test pada siklus 1 sampai dengan siklus II. Dengan demikian dapat disimpulkan bahwa penerapan model Problem Based Learning terbukti dapat meningkatkan hasil belajar IPA materi kelainan otot manusia pada peserta didik kelas V SD N Laren 04 . Hal tersebut sesuai dengan pendapat Kusumawat, (2015: 7) bahwa "Penerapan model Problem Based Learning untuk meningkatkan proses dan hasil pembelajaran peserta didik cukup efektif, terlihat dari kenaikan persentase keaktifan peserta didik pada setiap siklusnya".

\section{SIMPULAN}

Berdasarkan pembahasan dan hasil penelitian maka dapat disimpulkan penerapan model Problem Based Learning untuk meningkatkan hasil belajar IPA materi kelainan otot manusia pada peserta didik kelas V SD N Laren 04 siklus II, ternyata sudah menunjukkan hasil yang maksimal. Hasil belajar yang diperoleh lebih baik dibandingkan pada saat pelaksanaan kegiatan pembelajaran siklus I. Hasil yang diperoleh semua peserta didik menunjukkan kemampuan akhir yang lebih baik dibandingkan dengan kemampuan awal sebelum tindakan. Berdasarkan deskripsi pelaksanaan tindakan, hasil penelitian, dan pembahasan, diperoleh data adanya peningkatan hasil belajar IPA materi kelainan otot manusia pada peserta didik kelas V dalam setiap siklus. Kemampuan pada pra siklus $41 \%$ menjadi $66 \%$ pada siklus I dan meningkat pada siklus II sebanyak $75 \%$ meningkat menjadi $83,3 \%$.

Dari hasil pelaksanaan perbaikan pembelajaran dan refleksi siklus II maka dapat disimpulkan bahwa pelaksanaan tindakan pembelajaran dengan menerapkan model Problem Based Learning untuk meningkatkan hasil belajar peserta didik pada materi kelainan otot manusia dapat diakhiri pada siklus II dengan hasil yang memuaskan.

Berdasarkan kesimpulan yang telah diambil melalui analisis data yang terkumpul, dirasa perlu menyampaikan saran-saran sebagai berikut: Bagi peserta didik, diharapkan dapat mengoptimalkan penerapan model Problem Based Learning sehingga dapat meningkatkan pemahaman terhadap materi dan memotivasi peserta didik untuk memperoleh hasil belajar yang lebih baik. Bagi guru, dengan penerapan model Problem Based Learning memberikan dampak positif pada hasil belajar peserta didik, guru diharapkan dapat meningkatkan profesionalisme yaitu dengan mengoptimalkan penerapan model Problem Based Learning untuk meningkatkan kualitas pembelajaran. 


\section{DAFTAR PUSTAKA}

Amir, M. T. (2009). Inovasi Pendidikan Melalui Problem Based Learning. Jakarta: Media Grup.

Arikunto, S., Suhardjono, \& Supardi. (2008). Penelitian Tindakan Kelas. Jakarta: Bumi Aksara.

Arikunto, Suharsimi, dkk. (2011). Penelitian Tindakan Kelas. Jakarta: PT Bumi Aksara. Jayanti. (2019). Peningkatan Hasil Belajar IPA Materi Gaya Melalui Model Problem Based Learning (PBL) pada Siswa Kelas IV MI MA'ARIF Tingkir Lor Kota Salatiga Tahun Pelajaran 2018/2019. Skripsi

Kusumawat, W. (2015). Penerapan Model Problem Based Learning Pada Mata Pelajaran IPS Untuk Meningkatkan Hasil Belajar Siswa Kelas VI SDN Semboro 01 Kecamatan Semboro Kabupaten Jember. OPancaran, 4 (4), 1 12.

Purwanto, M Ngalim. (1997). Psikologi Pendidikan. Bandung: PT Remaja Rosdakarya

Rusman. (2012). Belajar dan Pembelajaran Berbasis Komputer. Bandung: Alfabetha.

Sani, R (2015). Pembelajaran Saintifik Untuk Implementasi Kurikulum 2013. Jakarta: Bumi Aksara.

Sugiyono. (2012). Metode Penelitian Kuantitatif Kualitatif. Bandung: Alfabeta

Suprihatiningrum, J.(2013). Strategi Pembelajaran: Teori dan Aplikasi. Yogyakarta: Ar Ruzz Media.

Uno, HB \& Muhammad, N. (2015). Belajar Dengan Pendekatan Pailkem. Jakarta: PT Bumi Aksara 